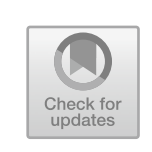

\title{
A Leader of Leaders
}

Different times need different leaders. In stable times, companies simply need a steady hand on deck, a leader who can manage the given and the expected with experience, expertise, and competence. But we are not living in stable times. A scientist describing the state of our world today would say that we are living "at the edge of chaos." This does not necessarily mean, as many of us fear, that we are living at the edge of an abys, that we are standing at the edge of a cliff and about to fall off. Rather, the scientific meaning of "the edge of chaos" is the state of a system poised between order and chaos, and it describes a state of maximum instability, a state of crisis when both the challenges and the opportunities are at their greatest. Crisis is often the mother of opportunity. It makes us realize that "the usual" no longer works. There are not the familar goalposts to act as guides and people are called upon to create new ones for themselves. It is the same at the edge of chaos. The biggest challenge facing leaders in the twenty-first century is the uncertainty and rapid change of events and technologies. This is a time for creativity and reinvention, requiring both the leader and his/her organization to be creative.

The whole purpose of Quantum Management Theory is to describe the leadership thinking and organizational transformation required to maximize creativity and the adaptability it requires. We have seen that in the quantum world, any kind of outside interference or control destroys both. In material quantum systems, any outside interference 
such as observation or measurement causes the Schrodinger wave function to decohere, and all the multiple, superimposed potentialities offer just one reality. In living quantum systems, complex adaptive systems, outside control alienates the system's self-organizing relationships and destroys their holistic cocreativity. In companies, top-down management administered through layers of bureaucracy does the same thing, greatly diminishing both adaptive response to rapid, or unforeseen, change, and innovation. Companies burdened with bureaucracy are slow-moving dinosaurs, their heads too distant from the ground their feet must navigate.

Quantum Management principles call for hands-off leadership at the top and the removal of middle management, replacing them with a coordinated network of self-organizing teams empowered to make decisions "at the front-line." In the resulting quantum company, all employees become leaders and the CEO is now a leader of leaders. This demands both very different leadership qualities, and a new, quantum, leadership philosophy. It demands new leadership vision.

\section{The Vision of the Quantum Leader}

Quantum leaders practice the very essence of quantum thinking, thinking that takes us beyond the boundaries of all that was known or has existed before. They lead from a deep level of revolutionary vision. They change the system, invent a new paradigm, clear a space where something new can be. Zhang Ruimin is such a business leader in China, wanting to create a company where employees could develop their full potential and to create a kind of relationship with customers that had never existed before. Steve Jobs was such a leader, wanting to create a technology that would change people's lives. Elon Musk is such a leader, over and over again achieving what others had never thought of or had thought was impossible.

Quantum leaders achieve this not just from "doing” but, more fundamentally, from "being." They are servant leaders in the truest sense of that term. They serve possibility, the not yet born. Such leaders are essential to deep corporate transformation.

The unicorn has always been a special symbol in human culture. He is that most impossible creature of the human imagination, a beast conjured up by longing and the human capacity to dream, conjured up by passion and given space to be by those who dare to believe in the mere possibility 
that he might exist. Today, all new start-ups are called unicorns, and the leaders I have mentioned have fathered many. As we have seen, Haier China is a company of start-ups, a company of unicorns. The same is true of Tesla.

In quantum science, the whole of existence is a vast reserve of possibilities just waiting to be drawn up from the quantum vacuum's infinite sea of possibility. Some of these possibilities are plucked out by "observers," human beings just living our lives, asking our questions, making our experiments, and initiating projects. An awareness of their role as cocreators of existence can increase quantum leaders capacity to fulfill that role. They serve more than company or colleagues, more than markets or products, even more than vision and values as these are normally understood. They serve that longing that conjures up unicorns, and through their service they build successful, profitable companies that add some new dimension to both business and human well-being. Quantum leaders are servants of the quantum vacuum, of the very heart of our universe and its manifold potentiality.

Most entrepreneurs start a business because they look at the market and see that there is some opportunity to offer a new service or product. Others do so because they have a certain skill or talent they feel they can take to the market environment. But the motivation of the quantum entrepreneur is more spiritual, arising from a feeling of inner necessity, a sense of deep passion. They say, "This has to exist! This has to happen! I have to do it!".

At the very beginning of his treatise on the art of strategy, Sun Tzu says, "Command your people in a way that gives them a higher shared purpose." Human beings are first and foremost creatures of meaning and purpose. This is what defines us as a species. We have a spiritual intelligence (SQ) that makes us seek meaning and purpose, and when we find it, it gives our lives and our work a sense of direction. We become highly motivated, highly productive. Employees who work for a visionary company find this sense of meaning and purpose because their leader's own purpose and passion permeates and inspires the company culture and is embedded in the very work challenges and opportunities they face each day on their jobs. They feel they are part of something big, something larger than themselves.

${ }^{1}$ Sun Tzu, The Art of War, Chap. 1, Line 15. 


\section{The Philosophy of the Quantum Leader}

In his Art of War, the very first of the five principles that Sun Tzu outlines for successful leadership is, "Know your philosophy." 2 By this he means, know the values and principles that define your strategic mission, and embed them in the culture shared with those whom you lead. I argued much the same throughout Part I of this book when presenting the philosophical ideas and values that arise from a new paradigm, or world view, derived from the defining principles of quantum physics and the quantum universe it describes. I deeply believe that Quantum Management, and the decision to implement it through some adaptation of Haier's RenDanHeyi management model, commits leaders to a new leadership and management philosophy that is itself a philosophy of life. Here, I want to outline the basic principles of this new leadership philosophy:

- Quantum leaders know that everything is connected to everything, everything is part of everything, and thus that they and the company they lead are part of the universe itself. The best way for their company to be sustainable, evolutionary, and innovative is for the leader to follow the same principles that assure that for other quantum systems, and imbed them in the company operational structures.

- Quantum physics tells us we live in a participative universe and that, through our questions, decisions, and projects, we human beings co-create reality. We make the world we live in. Quantum leaders know they play a role in making the world, and thus that they have responsibility for the world. As company leaders, they meet this responsibility by building good companies that generate the wealth and create the conditions that will contribute to making the world a better place for their shareholders, employees, customers, and the community in which they operate. And they know all this includes a responsibility to protect the environment on which everything and everyone depends-including themselves and their companies. Quantum leaders give up power, but they never give up responsibility. They will always be responsible for overall mission guidance and execution, company vision, company morale, and the nature of company culture.

${ }^{2}$ Sun Tzu, ibid., Chap. 1, Lines 6 and 14. 
- Quantum leaders know that quantum physics tells us every person plays a unique role in constructing the shared web of reality that we call our world, and that every employee of the company is an active player in making it what it is. They know there are no "little people," no "unimportant people" in their organization. Each employee is an equal partner in the company's shared enterprise, and an equal contributor to its success-a fellow leader. Recognizing this unique value of every employee, quantum leaders accord each of them dignity and respect, regardless of role or status.

- Quantum leaders know that the universe itself possesses infinite potential, and that human potential is infinite. They are committed to giving each employee the opportunity to achieve his or her own best potential, knowing this best realizes company potential. They also appreciate market potential and the infinite potential of customer needs, and are always looking for ways more fully to develop the company's own potential through new structural, product, and service innovations.

- Quantum leaders know that living systems are the most complex and creative systems in the universe. They appreciate the value and promise of life itself, and thus are committed to ensuring the best quality of life for employees through working conditions and rewards, and best improving the quality of life for customers through products and services. They do not expect employees to endure conditions they could not endure, nor customers to accept products and services they would find unacceptable. Quantum leaders always want to give value, to add value, to enrich the fabric of life itself.

- Quantum leaders know the universe itself develops its potential and innovates through the creation of ever new, borderless relationships, that the universe is an ecosystem. They are committed to building an internal ecosystem by nurturing and developing internal, collaborative, win/win relationships between employees and self-organizing teams within the company, and to building an external ecosystem by nurturing and developing cooperative, win/win relationships with customers, the community, and other companies. They are committed to the principle of Zero Distance. 


\section{The Character of the Quantum Leader}

Business leaders are usually judged by their ability to deliver a healthy bottom line for shareholders, not by the quality of their personal character. Indeed, many are even admired for being "tough bastards" or unprincipled rogues. The culture of business-as-usual depends on greed, self-interest, and amoral decision-making. Adam Smith declared these to be founding assumptions of capitalism. An ability to wield and leverage power is what matters, and any moral flaws or consequences be damned. While it is all too obvious that moral flaws do have consequences for companies, corruption being a large contributing factor in today's leadership crisis, there are other reasons why the quality of a leader's personal character now trumps an ability to wield power.

We have seen that if companies are to become agile and resilient in the face of twenty-first-century challenges, leaders must surrender most of their accustomed power. In a quantum company, the leader's job is to motivate, inspire, be a role model for the company culture, and to serve the needs of employees who have now become leaders in their own right. Thus a quantum leader's character and integrity becomes a matter of great importance. Can they be trusted to have our backs? Do they walk the talk? Are they honest with us? Are they someone we can look up to? Thus for quantum leaders, it is not so much what they do that matters, but rather what they are. This requires a very different path to leadership development. Leadership development becomes personal development, character development.

- Perhaps the most important process required for personal development is increasing self-awareness, learning to know ourselves, who we are in different situations and with different people, getting to know our own feelings, what makes us happy and what we dread, how we respond to others and why, what we most aspire to and the fears or hesitations that hold us back, what motivates us and what we need to do to act from higher or more positive motivations, why some things make us angry and what better we can do to control that, why we find some things difficult, why we embarrass ourselves sometimes, why we need to control things, etc. Increasing self-awareness is a life-long process because the self is a process. Who we are changes and develops over time, and we need frequently to catch up with ourselves, to see where we are now and set the goals 
for what has to be accomplished next. Such self-examination and awareness cultivates the emotional intelligence we need to understand, empathize with, and lead others. Each of us is unique, but each of us also has an awful lot in common.

- Another important dimension of character is vulnerability, and the authenticity it creates. Business leaders are expected to be strong, to have all the answers, to be the one everyone can lean on or turn to, who can make the right things happen, who never say "I don't know" or "I need help with this." They were never such allpowerful superheroes, but they had to pretend. That made those who worked with them or for them have to pretend, too. It creates a false company culture that everyone here always knows what they're doing, never makes mistakes, never needs help. It creates the fear and the risk-aversion that dominates so many company cultures, the cover-ups and the blame-games, and in fact increased incompetence. Quantum leaders have the humility, the integrity, and the wisdom to own up that they, too, are vulnerable, they, too, make mistakes, they, too, need the help of others, their input, their different or greater expertise, their different way of looking at things. This sets an example and creates a culture of mutual reliance, a culture of safety. It also leads to an authenticity that builds trust.

- Today, character is also a factor of competence. In the Zero Distance quantum world, no company or organization is an island, and narrow expertise in just one area of life or work is no longer sufficient for any effective person. For a business leader, such insular narrowness is simply a recipe for incompetence. Thus breath and depth of character is essential for quantum leaders, a trajectory of constant personal growth. Just as it takes a lifetime to know oneself, it takes a lifetime to become oneself. Each of us has infinite potential, but potential must be nurtured and developed if it is to be realized. Quantum leaders are committed to a lifetime of self-cultivation, a lifetime of learning and exploration. They are always expanding their horizons, adding to their skills, exposing themselves to new ideas, new people, new situations. They are cultured, aware of the big ideas in the arts and sciences. They know today's world is fast, uncertain, and complex and the knowledge and experience they will need may come from anywhere. The character they grow will come from the effort they make to expand that. They know that to make the world, they must make themselves. 
Quantum leaders are also committed to becoming better people. Moral self-cultivation has long been a fundamental principle of Chinese thought. The followers of Confucius believed all human beings are born with an innate knowledge of the good but that we must devote our lives to nurturing and developing this. The same has been the goal of all the world's great spiritual traditions, and is the point of most spiritual rituals and practices. The quantum leader's commitment to moral self-cultivation makes his/her leadership a spiritual practice.

\section{The Quantum Leader as a Crisis Leader}

During the early months of the Covid-19 crisis, several people commented in the New York Times and elsewhere that America needed a "crisis leader," and there were various descriptions of the qualities such a leader must have. The best of these, I thought, was written by General Stanley McCrystal, former commander of the American Army's Joint Special Operations Task Force in Iraq, and his officer colleague Chris Fussell, who made the further observation that the need for crisis leadership is here to stay, an ongoing necessity for all twenty-firstcentury organizations. They believe the twenty-first-century leader must, in essence, be a crisis leader. The qualities they say are required in a crisis leader offer a good recap and summary of the qualities necessary in a quantum leader. Thus I want to end by quoting them:

- "Leaders must be visible with their plans, honest with their words and adaptable with their actions - all while maintaining compassion for the situation and the impact it is having on their team.

- Be seen to be there as a leader, show calm in the midst of chaos;

- Be honest with your team, even if this feels uncomfortable;

- Give up more authority than feels natural. Fighting through complexity requires quick and informed action at the edge...Organizations will need teammates making independent decisions close to the points of action, not waiting for directions. It's tempting in times of crisis to grab the reins and yank back, but this will be more disruptive than it is helpful. Be connected, listen and adapt based on what your front line is telling you;

- Be more compassionate than you think you need;

- Use digital communication to stay in touch with your people in the field. The Joint Forces command where both of us served, needed to 
do this exact thing. We pivoted from being a centrally located, thousands strong enterprise to a network of small teams spread around the world.

- Connect, learn, listen, and inspire a team."3

We will see more of General McCrystal's leadership philosophy and practices and how these altered critical American Army operational procedures in Chapter 19.

We saw in Chapter 5 that the Taoists believed that Man is the bridge between heaven and Earth. Reflecting this, quantum philosophy sees our purpose as human beings is to embed the cosmic principles of the universe in the projects we build here on earth. By building quantum companies managed according to those principles, quantum leaders are fulfilling that purpose. After giving a speech at INSEAD in November 2019, Zhang Ruimin was asked what advice he would give to young people today. $\mathrm{He}$ said, "The greatest thing that I believe a young person can do with his or her life today is found a company."

Open Access This chapter is licensed under the terms of the Creative Commons Attribution-NonCommercial-NoDerivatives 4.0 International License (http:// creativecommons.org/licenses/by-nc-nd/4.0/), which permits any noncommercial use, sharing, distribution and reproduction in any medium or format, as long as you give appropriate credit to the original author(s) and the source, provide a link to the Creative Commons license and indicate if you modified the licensed material. You do not have permission under this license to share adapted material derived from this chapter or parts of it.

The images or other third party material in this chapter are included in the chapter's Creative Commons license, unless indicated otherwise in a credit line to the material. If material is not included in the chapter's Creative Commons license and your intended use is not permitted by statutory regulation or exceeds the permitted use, you will need to obtain permission directly from the copyright holder.

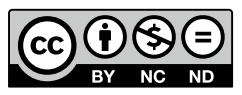

3 Stanley McCrystal and Chris Fussell, "Fight Coronavirus Like We Fought Al Qaeda," New York Times, 24 March 2020. 